\title{
XXXVIII. 最適化
}

編 集 西 村 維*.大高易 男**

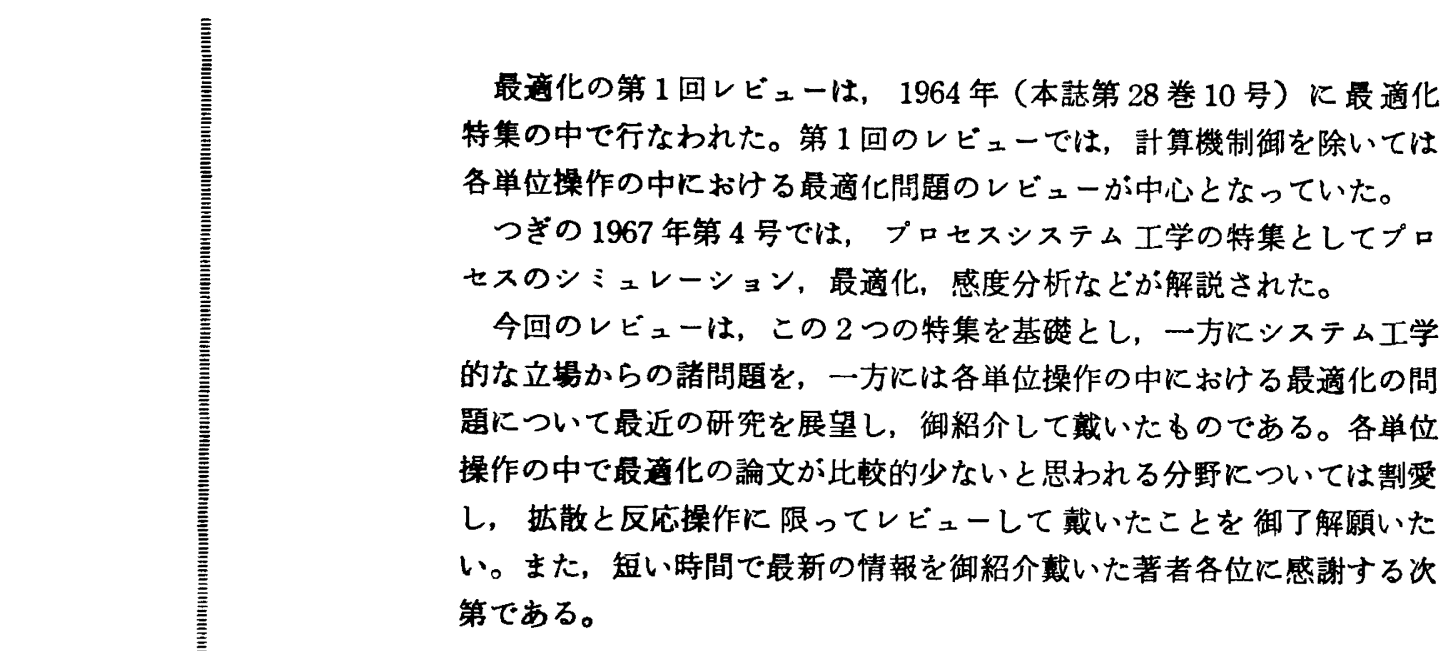

I. プロセスシステムエ学と最道化

1. 展望

西村䇤*

今回プロセスシステム工学を中心とするレピューを行 ならことになった。これは、はじめ取暗化のレビューと して企画されたすのであるが，二，三の執䇤者の方々と 相談しているらちに，取通化という枠にかならずしると らかれずに，フロセスシステム工学の中です取近特に発 展が目さむしいいくつかの分野をえらんで報告してみよ らということになり, プロセスシステム工学を中心とす

- Hajime Niohimura (正会全) 果京大学工学部化学科

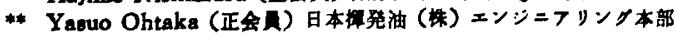

・昭和 47 年 8 月 28 日受理
ろレビューというょうな形に落着いたものである。した がってこれはプロセスシステム工学に関する完全なレビ ニーを意四したものではない。えらばれた項目す「構成の 最適化」といらょらな理論面での分類と，「計算機制御」 といらような技術面での分類が交錯しており，しかも網 羅的ではない。たとえば,「システムの感度解析」とか， 「システムの安定性解析」といらような重要な項目も紙 数の関係で割爱せざるをえなかった。

このレビューが以上のような性格のものであるし，ま 
たプロセスシステム工学といら学問が誕生間もなく、し かむ発展変ぼ5の絶え間ない分野であるので，はじめ に，プロセスシステム工学の現状について簡単な展望を おこないここで取り上げた各項目について位置つけを 行なってみたいと思ら。読者諸賢のご参考になれば幸で ある。

\section{プロセスシステム工学の形成}

ここ数年のうちに，わが国ではプロセスシステム工学

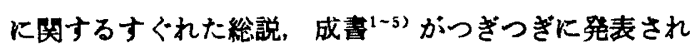
た。外国であ同様であっだー9)。これらを見るとプロセ スシステム工学は一体何であるかとい5点に成しては, 研究者によって考えがさまざまである。これに関して は，それぞれの著作なり論文なりを通して理解していた たくことにして，ここでは，プセスシステム工学とい ら分野かどのようにして形成され，何を基礎にしている のかをまず説明しょら。

プロセスシステム工学の源流としては，「ブロセス制 御」と「オペレーションズリサーチ(OR)」の二つをあ げることができる。このち前者は、フィードハック制 御の技術を流量，王力，温度などの制御に適用すること によって,プロセス全体を設定された条件のとおりに正 確に，しかる安定に運転することを目的とするすのであ る。これに対し後者は，原料，市場などの環境条件に合 わせて、プロセス全体の運営を最通にするよらな運転条 件を見出すことを目的としている。つまり ORは運転 条件を決め、プセス制御はこれを実現する形になって いる。

1955 年以降，わが国では化学ブラントの計装化、自 動化は急速に進み，特に石油化学系のブラントでは，フ 口セス制御はかなり早い時期に实用的に見て一応満足で きるレペルに達したと考えられる。ORす，たとえば石 油精製工莱では，は中くから実用されて来た。ここで は, ガソリン, 灯油, 重油など各製品ごとの需要予想に もとついて原油の買付計画、タンカーの配船計画, 各装 置の稼動計画などを線形計画法 (LP) を用いて最通に決 定することがおこなわれて来た。

システム工学の目的が，システムに関する最適な計画 を作りっこれを安定に確実に実現することにあるならば， プロセスシステム工学は，1960年代のはじめにはすで に存在していたといえるだらら。しかしながらこれた けならば，自動制御理論や OR 理論の化学工莱への適 用とはいいえても，プロセスシステム工学といら独自な 分野の誕生とはいえないであろう。

フロセスシステム工学と呼へろためには，フロセス自 体の理諭的な把暒といら亭が心になって，制御の問題
む運営の問題も共通の基磷に立って論ぜられるよらにな らなければならないからである。

そのためには，化学工学の中心分野であるプロセス設 計の分野が，制御中 OR を中心とするシステム工学理論 と本格的な接触をし，フロセス設計の考方方や方法が ステム工学的な考え方と方法で体系化され，統一される ことが必要であったと思われる。

つまり，プセス設計の分野で、システム工学的な最 適設計の方法が確立される見通しができた時がプロセス システム工学の誕生といえるだろう。

この時期は当然のことなから，化学工莱の分野でかな り自由に計算機が利用できる見通しができた時期と一致 している。

このよらな理由から、プロセスの取適設計をたは, フ ロセスの最適化といらのがプロセスシステム工学の原点 になっているといえるだろう。

\section{プロスシミュレーション}

プロセス最通化に必要なものは,プロセスシミュレー ションの技術と取通化の方法である。

プロセスシミュレーションをおこならには，要素とな る部分についての数学モデを確立することとこれら を組合せてえられる連立方程式を解くための手法が必要 になる。

数学モデルとしてはどの程度のものか㴗求されるかと いらことは，フロセスシミュレーションが何に使われる かによってことなるか，フロセスの最暗設計に使らため

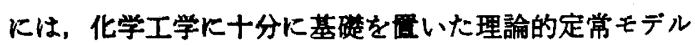
が必要となろう。既存ブラントの最道運転のためには， 非定常モデルを含めた正確なモデルが必要となるかも知 れないか，この場合は，一般に適用筑囲もせまくてよ く，さらにブラントの実就データが使えるのでモデルは 简単になるであろら。

このよらなモデルを組合わせてシステム全体の特性を 求める場合，各モデルが非線形であったり、システムが リサイクル柫造をるつ場合は，実際に解を求めることは 容易でない。

これは非線形の連立方程式になるが，連立方程式を解 く計算手順を決める問題と, くり返し計算の収束速度と 収束の安定性が問題になる。個々の問題については, 計 算手順は人間が考えてもよいか，沉用シミュレータを作 る場合は, システムと数学モデルの構造に応じて自動的 に計算手順を决めるよらな方法が必要になる。これには グラフ理論が非常に有効に使える

しかしながら収東性の問題は別であって，ダフ理論 だけから速い安定な収束をする計算法を見出すことはで 
きない。特別な形をした連立方程式には，有奻な万法が 知られているが，一般に通用する規則はまだ十分に明ら かにされていないよらである。

\section{最薏化の方法}

最通化の理論と方法はシステム工学の中でも特に研究 が盛んな分野である。たとえば，MPゃDPがそのよい 例である。これらはその商用対象にかなり限界はあるす のの, 問題の本質を明らかにするよらなすぐれた方法で あるといらことができる。

システムモデルと最適化の方法といらのは，無関係に 独立なあのと考えるべきでなく、システムの構造，モデ ルの性質からえらぶべき最道化の方法がきまり，逆に最 音化の方法から、モデルの性質、評価阙数の形に関して 要求が出て来るといら性質のるのであろら。このように して最道化の方法が問題の性格によくマッチした時, 目 覚ましい成果が得られるのである。

最道化の方法としては実にさまざまな方法があるが， プロセスシステムに通した方法として特に，階屏的最通 化の方法に注目すべきであると思ら。これはシステムの 最高化問題を，各サブシステムの最高化問題と，システ ム全体としての最音化問題との二つのレベルに分け，二 つのレベルの間の協調を取りながら最音化を進める方法 で,プロセスシステムのように最竞化すべき変数が多 く、システムの構造が复䧴な場合に通していると思われ る。この種の方法にも幾通りるのやり方がある。

\section{プロセスシステム工学の理的発展}

一段飞理論体采を摭張発展させる原動力は二方面に分 けて考えることができると思ら。一つは純䉽に学問的な あのであって，現在の理論の制約となっている諸条件を つぎつぎに取り払ってゆこらとする努力である。たとえ ば，線形から非線形への拡張，定常釉ら非定常系への 执張, 確定系から不確定系への拡張などである。フロセ スシステム工学でも，たえずこのような努力がつづけら れている。

しかし一般にX系から非 $X$ 系への抬張とい5点で気を つけなければならないことは，X手は具体的内容をすっ ているか，非 $X$ 和具体的内容がないからこそ非 $X$ 釆な のであって，このままでは理論的取扱いが成功するはず がないといらことである。

理論を進めるためには非 $X$ 系の中から，何か具体的な 内容をすった部分をすくい出して来る必要がある。不確 定系の中に確率分布とい5概念を等入し，肃定常系の中 К定常確咟過程という概念を等入するのはこのためであ
る。

もらろんこのよらな抽象化をおこなってもそのあとの 理論の展開は，もとのX系にくらべてはるかにむずかし く，具体的な結論がえにくいことは覚悟せねばならな い。したがって非 $X$ 釆への理論の拡張にあまり大きな期 特を掛けることは禁物である。

しかしながら，不確定要素をむつプロセスシステムの 最適設計の理論に执いては不確定性要素の性格をらまく 限定して，近似的に理論をすすめている高松らの仕事 ${ }^{10)}$ は実祭に大いに参考になろう。

\section{システムの拡大}

理論を执張させるもら一つの契機は，技術の目的から 見た実際上の必要性である。プロセスを最通に設計する といら技術目的の钼点から現状のプロセス最暗化技術を 見てみると，たとえそれが完全におこなわれてもまだ不 十分な点があることに気つく。

一つは評価関数の中のパラメータの取り方である。製 品の価格, 特に中間製品中廃ガスの価格づ，隣接プロ セスからスチームなどを導入した場合の用役費の評価な とが問題になる。

これは広い意味でいえば, 全システムを注目するシス テムと環境に分けた時, 環境の条件をあらわすバラメー タである。しかしなから，システムとその環境への分割 といら方法は, つね便宜的なすのであって, 全体を本 当に最䔔化しょうとするならば，今まで環境と考えてい たものまでむ，システムの中に含めて最缡化を考えねば ならない。こよらに取薏化を追求すればどらしてもシ ステムの簀囲はひろがって来ざるをえない。

いくつかのブロセスの間で中間製品や用役が受け渡し される场合これらに価格をつけて各ブロセスを最暗化 するのは便宜的な方法であって，本当はコンビナート全 体をシステムとして最䔔化せねばならない。

コンピナート全体の取道計画に関してもいくつかの仕 事が発表されているる゙。これらは，最終製品の需要量と 価格を環境条件にして，全体が物質収支をみたし，乙 かも取道になる上らに各ブロセスの規模を決定すること を目的としており，方法としては，普通 LPが用いられ る。

しかしなかららこのよらな报張の仕方は，やはり锶念的 であって，実際的钼点から見るとはなはたしく不十分で あるように思える。それはシステムがコンビナートぐら い大きくなると，その計画にあたっては一つには，需要 構造や原料条件などかなり長いタイムスケールでおこる 変化を予測することなく計画を進めることはできないと いらことであり,むらーつには, コンビナートが大きけ 
化」

れば，それが地域社会やまわりの自然環境に与える影籍 を予測することなく，計画を進められないといらことで ある。

このようにして社会経済的な予測をらくめ自然環境の 予測をおこなら環境システム論がこれからのプロヒスの 計画には重要になるであろら。

\section{システム灣造の最䔔化}

実際的な技術目的から見た理論への要請として，取適 なシステム構造を理論的に決定する方法はないかといら 問題がある。実祭のブロセス最薏化では，経鈳を穔んだ 人が最䔔思われるフローパターンをいくつかえらび, それぞれとついて最通化をおこなったあとで，相互の比 校をおこなって最道なバターンを决定している。

そこで最着なフローバターンを決定をするための有効 な理論的方法はないかといらことが問題である。この夙 題には二つのアプローチがある。一つは特にしばしば問 题となるよらなシステムについて，それを近似的に表わ ししかす理論的取报いが简単になるよらな理想的システ ムとい5すのを考光，この理想的システムについて，取 道な構成を具体的な規則の形で示す方法である。これは 熱交奐系や蒸留系ではできている。これに対しこうい ら特別な近似をおこなわずに一般的な形で問題を报掞う とするアプローチがある。これは対象とするシステムに 制限がないことが利点であるか，具体的な結論を得にく いといら難点がある。

$$
\text { コンピュターコントロール }
$$

コンピューターヌントロールといら分頌は，技術の目 的に上る分類ですなく，学問の性格による分類でるな く，技術の形態に上る分類といらへききであら。
したがってコンビューターュントロールが何を目的に しているのかは，はじめから蚌っているわけではない。 一番単純な機能はデータロギングによるブラントの管理 であり，少し進んだ機能としては，それまでのアナロク 計器で行なわれていたブラント中のフィードバック制御 機能を計算機によって集中的に代替するすのがある。さ らに進んだ機能としては，企業の MIS (Management Information System) と連係を取りながら、プラントの 最適運転条件を決定してゆくものがある。

\section{ブロセスシステム}

フロセスシステムにおけるプロセスとは何かといらの はむずかしい問題である。常識的には，蒝留，反応など の単位缲作から作られるシステムをプロセスと呼ぶわけ たが，プロセスシステム工学の対象が広がるにれて, あっと一般性のあるとらえ方が必要になるだろら。

その一つとしてプロセスとは, 反応，払散，流動，层 熱などの物理化学的な変化過程だと考光，このようなプ 口セスが組み合わさってできるシステムの問題を取扱う のがブロセスシステム工学だといら考えができる。この 考えによれば，熱と物質の流れであらわされるシステム はすべてブロセスシステムといらことになる。その中に は化学プロセスばかりでなく，物質の循環をあらわす自 然棵境システムや，経済活動における物の流れをあらわ す投入産出分析す入って来ることになろら。

つまりプロセスシステムといらのは，機械関係のシス テム，土木成保のシステムといらよらな便宜的な分類の 中の一頁目なのではなく，論理的な手繶きの流れを設計 するのが諭理システムであるのと同じような意味で，原 理的な分頼であるといえよう。そして物筫と熱の流れの システムを解析したり設計する方法としてさらに発展さ せる必要がある。

引用文 嗝

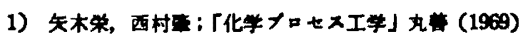

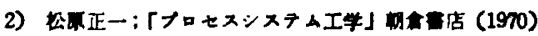

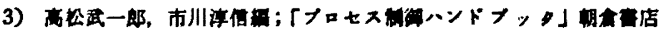
(1971)

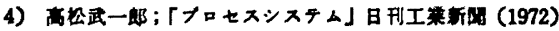

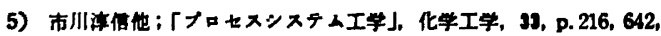
751, 1213, (1969)

6) Himmelblau, D. M. et al; "Process Analysis and Simulation." John Wiley and Sons (1968)
7) Rudd, D.F. et al ; "Strategy in Process Engineering", John Wiley and Sons (1969)

8) Нагиев, М.Ф.; теория рециркуяции и олтималъности химических процессов наука (1970) (化䒹プロ スのリサイ クルキよび震吉化の理触)

9) Наятмаии, К.; Analyse und Steuerung von Prozessen der Stoffwirdochaft, Akademie Verlag (1971)

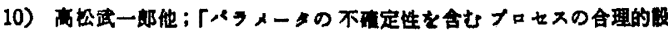

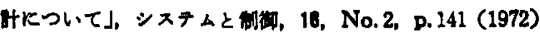

